\title{
Soft Tissue Sarcoma of the Trunk and Extremities cM0 TNM Finding v8
}

National Cancer Institute

\section{Source}

National Cancer Institute. Soft Tissue Sarcoma of the Trunk and Extremities cMO TNM

Finding v8. NCI Thesaurus. Code C136677.

Soft tissue sarcoma of the trunk and extremities without distant metastasis. (from AJCC 8th Ed.) 